\title{
FINANCIAL STABILITY OF ENTERPRISES IN SERBIAN AGRICULTURE, FISHING AND FORESTRY SECTOR
}

\begin{abstract}
Denis Kušter ${ }^{l}$
*Corresponding authorE-mail: kuschter@yahoo.com

A R T I C LE IN F O

A B S T R A C T

Original Article

Received: 21 May 2021

Accepted: 10 August 2021

doi:10.5937/ekoPolj2103745K

UDC 658.15:63(497.11)

Keywords:

financial analysis, financial stability, agriculture, ROA, ROE

JEL: M41, O13, Q14

The main aim of this research paper is to examine financial stability, including indebtedness, interest coverage, and profitability of enterprises in Serbian Agriculture, fishing, and forestry sector. The research was performed using the tools of accounting and financial analysis. Period from 2015 to 2019 was observed. Analysis was based on consolidated financial statements for all enterprises that belonged to the sector in mentioned period. Research results show that the enterprises managed to maintain acceptable level of long-term financial stability, while on the other hand, there was a more significant disturbance on the side of shortterm financial stability. Solid performances were recorded in the field of interest coverage, but also indebtedness where those indicators met referent values in almost every observed year. In the field of profitability that was examined via ROA and ROE indicators, poor performance was recorded.
\end{abstract}

(C) 2021 EA. All rights reserved.

\section{Introduction}

The sector of Agriculture, fishing and forestry is also known as "Sector A". This sector of the economy is extremely complex and includes many activities such as growing crops and plantations, animal husbandry, forest exploitation, but also production of animal origin products on farms. Agriculture in the Republic of Serbia has economic, social, and political importance. Significance of agriculture can be observed through participation of employees in agriculture in total number of employees. Almost $1 / 4$ of employees are in agriculture (Kuzman et al., 2017). In the Republic of Serbia there is a disproportionate ration between a number of rural populations and their share in the creation of GDP, unlike the EU countries. Only 5\% of the EU rural population participates with $15 \%$ in GDP of the Union, while in Serbia a larger number of rural populations takes part in the creation of GDP lower value (Mitrović et al., 2017). By the early 1980s Serbia had experienced significant growth in agricultural production which stagnated in the late 1980s and declined sharply in the 1990s (Bogdanov \& Rodić, 2014). Period from 2000 to

1 Denis Kušter, PhD student, University of Novi Sad, Faculty of Economics, 9-11 Segedinski put, 24000 Subotica, Serbia; Phone: +381 642563340, E-mail: kuschter@yahoo.com, ORCID ID (https://orcid.org/0000-0001-6697-6792)

http://ea.bg.ac.rs 
2008 was characterized by substantial annual fluctuations of agricultural production, but generally it is still lower than in pre-transitional period (Bogdanov \& Vasiljević, 2011). The period after 2010 was marked by significant policy changes.

Serbia has a favorable geographical position, but also great potential when it comes to agriculture, forestry, and fishing, so this sector deserves a deeper analysis of financial performance. The analysis will be conducted based on consolidated financial statements (balance sheets and income statements) for all enterprises that made up the abovementioned sector in period from 2015 to 2019. The main aim of this research is to show financial stability and profitability of enterprises in Serbian Agriculture, fishing, and forestry sector, but also to give recommendations on how to improve or maintain mentioned financial indicators in the coming period.

\section{Materials and methods}

The research sample includes all the enterprises that were classified in the Agriculture, fishing, and forestry sector (Sector A) on the territory of the Republic of Serbia in period from 2015 to 2019.

Table 1. Research sample

\begin{tabular}{|l|c|c|c|c|c|}
\hline \multicolumn{1}{|c|}{ Category / Year } & $\mathbf{2 0 1 5}$ & $\mathbf{2 0 1 6}$ & $\mathbf{2 0 1 7}$ & $\mathbf{2 0 1 8}$ & $\mathbf{2 0 1 9}$ \\
\hline Number of enterprises & 3,460 & 3,673 & 3,756 & 3,939 & 3,932 \\
\hline Number of employees & 33,472 & 32,244 & 32,023 & 32,330 & 31,247 \\
\hline
\end{tabular}

Source: Authors' interpretation based on FSAB data

The research is based on the Annual Financial Statements Bulletins (FSAB) that are available on the Business Registers Agency official webpage. These Bulletins contain data related to financial statements of entities in real sector. Also, they include information related to number of entities and employees per sector. To be more precise, the financial analysis is performed via consolidated balance sheets and income statements for all enterprises that were classified in "Sector A". (Table 1.)

Table 2. Growth tendencies of Agriculture, fishing, and forestry sector

\begin{tabular}{|l|c|c|c|c|c|c|}
\hline \multicolumn{2}{|c|}{ Category / Index } & \begin{tabular}{c} 
Ind. \\
$\mathbf{2 0 1 5 /}$ \\
\multicolumn{2}{|c|}{}
\end{tabular} & $\begin{array}{c}\text { Ind. } \\
\mathbf{2 0 1 6} / \\
\mathbf{2 0 1 5}\end{array}$ & $\begin{array}{c}\text { Ind. } \\
\mathbf{2 0 1 7} \\
\mathbf{2 0 1 6}\end{array}$ & $\begin{array}{c}\text { Ind. } \\
\mathbf{2 0 1 8} / \\
\mathbf{2 0 1 7}\end{array}$ & $\begin{array}{c}\text { Ind. } \\
\mathbf{2 0 1 9} \\
\mathbf{2 0 1 8}\end{array}$ \\
\hline & Number of enterprises & 101.4 & 106.2 & 102.3 & 104.9 & 99.8 \\
\hline Number of employees & 97.4 & 96.3 & 99.3 & 101.0 & 96.7 \\
\hline
\end{tabular}

Source: Authors' interpretation based on FSAB data 
For the research to be conducted methodologically accurate and precise, it is necessary to set several starting points. Balance sheets have separately presented Deferred tax assets and Deferred tax liabilities positions. Therefore, position Deferred tax assets had to be associated with short-term or long-term assets, while balance sheet position Deferred tax liabilities had to be associated with either short-term or long-term liabilities. Deferred tax assets were treated as part of long-term assets, while deferred tax liabilities were treated as a component of long-term liabilities. Subscribed capital unpaid balance sheet item was abstracted from the analysis on the Assets side, but also from Equity. Off-balance sheet assets, off-balance sheet liabilities and loss above equity are also out of analysis scope.

The research was performed based on the following steps:

1. Long-term financial stability analysis. Long-term financial stability is present when long-term tied assets are equal to equity increased by long-term liabilities. (Rodić, et al., 2017). Examination of conditions for establishment and maintenance of long-term financial stability requires consideration of relationship between long-term liabilities and long-term tied assets. (Miljković, 2008). The analysis of the relationship between long-term assets and long-term liabilities will be performed using the Long-term ACID test.

2. Short-term financial stability analysis. Short-term financial stability is expressed through the liquidity of a company. It refers to the ability to pay due liabilities within maturity. Liquidity is a company's ability to raise cash in the short term to meet its obligations. Liquidity depends on a company's cash flows and the makeup of its current assets and current liabilities (Subramanyam \& Wild, 2009). Determinants which affect liquidity are overdue liabilities, deadlines and means of payment (Vunjak, 2011). The analysis of the relationship between short-term tied assets and short-term liabilities will be performed using the Short-term ACID test.

3. Indebtedness analysis. Indebtedness is assessed through the liabilities structure. The more the structure of liabilities is shifted towards equity, the more favorable the ratio of assets and debts is, hence the lower the probability is that the debtor's losses will be higher than equity (Rodić, et. al, 2017). Indebtedness ratio is the measure used in analyzing financial statements to show the amount of collateral available to creditors (Nuryani \& Sunarsi, 2020).

4. Interest coverage analysis. Interest coverage ratio measures the number of times a company's earnings could cover its interest payments. A higher interest coverage ratio indicates stronger solvency, offering greater assurance that the company can service its debt (i.e., bank debt, bonds, and notes) from operating earnings (Robinson, et. al, 2009). This ratio indicates the amount by which income from operations could decline before a default on interest may result (Dauderis and Annand, 2014). 
5. Profitability analysis. Profitability of the concern purely depends on the effectiveness and proper utilization of funds by the business concern (Paramasivan $\&$ Subramanian, 2009). Profitability ratios are indicators of the overall efficiency (Kabajeh et al., 2012). The profitability ratios based on sales are profit margin and expenses or operating ratios. The profitability ratios related to investments include return on assets, return on capital employed, and return on shareholders' equity (Kulkarni and Mahajan, 2008). Profitability analysis of enterprises in Agriculture, fishing and forestry sector will be conducted using Return on assets (ROA) and Return on Equity (ROE) ratio indicators. ROA measures the ability to utilize assets in order to create profits, by comparing profits with the assets that generate those profits (Gibson, 2000). ROE of a company is affected by two factors: how profitably it employs its assets and how big the firm's asset base is relative to shareholders' investment (Palepu et al., 2000). ROE measures a firm's productivity of equity and therefore provides an indication of its ability to attract a form of capital that provides an important cushion for the debt holders (Fridson and Alvarez, 2002).

The main question that arises is how financially stable enterprises in Serbian Agriculture, fishing and forestry sector are, as well as whether the above-mentioned indicators strive towards improvement or deterioration. Following hypothesis are set:

H1: Enterprises in Serbian Agriculture, fishing and forestry sector manage to maintain acceptable level of long-term financial stability: the share of short-term sources of funds in the financing of long-term assets does not exceed $20 \%$ during observed period.

H2: Enterprises in Serbian Agriculture, fishing and forestry sector do not manage to maintain acceptable level of short-term financial stability: short-term liabilities maturity needs to be extended in average by $50 \%$ or more compared to the maturity of shortterm tied assets in whole observed period to maintain liquidity.

H3: Indebtedness and interest coverage ratio indicators of enterprises in Serbian Agriculture, fishing and forestry sector have an improving tendency during observed period.

H4: Profitability ratio indicators (ROA and ROE) of enterprises in Serbian Agriculture, fishing and forestry sector have an improving tendency during observed period.

\section{Results}

Long-term tied assets, but also equity and long-term liabilities had increasing trend over observed period. During the timeline, the balance sheet position Immovables, plants, and equipment had the most significant growth within long-term tied assets category (up to $8 \%$ ).

In recent years, long-term financial investments have grown significantly. Long-term stability coefficient was slowly decreasing during time as consequence of more rapid equity and long-term liabilities growth compared to long-term tied assets. (Table 3) 
Table 3. Long-term financial stability analysis [balance sheet positions in $\mathrm{KRSD}^{2}$ ]

\begin{tabular}{|l|l|c|c|c|c|c|}
\hline$\#$ & Category / Year & $\mathbf{2 0 1 5}$ & $\mathbf{2 0 1 6}$ & $\mathbf{2 0 1 7}$ & $\mathbf{2 0 1 8}$ & $\mathbf{2 0 1 9}$ \\
\hline 1 & Permanent assets & $456,451,679$ & $538,009,438$ & $566,877,614$ & $593,820,519$ & $614,517,321$ \\
\hline 2 & Inventories & $92,555,989$ & $95,698,975$ & $103,430,194$ & $104,895,695$ & $106,650,261$ \\
\hline 3 & Deferred tax assets & $3,545,592$ & $2,828,254$ & $2,502,694$ & $1,471,281$ & $1,404,088$ \\
\hline $\mathbf{3}$ & $\begin{array}{l}\text { Long-term tied } \\
\text { assets [1+2] }\end{array}$ & $\mathbf{5 5 2 , 5 5 3 , 2 6 0}$ & $\mathbf{6 3 6 , 5 3 6 , 6 6 7}$ & $\mathbf{6 7 2 , 8 1 0 , 5 0 2}$ & $\mathbf{7 0 0 , 1 8 7 , 4 9 5}$ & $\mathbf{7 2 2 , 5 7 1 , 6 7 0}$ \\
\hline 4 & Long-term loans & $74,346,741$ & $81,695,739$ & $87,439,004$ & $108,465,296$ & $118,553,466$ \\
\hline 5 & $\begin{array}{l}\text { Long-term } \\
\text { provisions }\end{array}$ & $\mathbf{6 , 2 7 0 , 7 9 6}$ & $6,627,205$ & $6,630,765$ & $4,797,176$ & $3,871,526$ \\
\hline 6 & $\begin{array}{l}\text { Deferred tax } \\
\text { liabilities }\end{array}$ & $\mathbf{6 , 7 5 4 , 8 2 3}$ & $7,514,431$ & $8,294,170$ & $8,635,402$ & $7,885,931$ \\
\hline 7 & Equity & $391,297,105$ & $479,930,567$ & $507,177,337$ & $523,010,096$ & $543,983,077$ \\
\hline $\mathbf{8}$ & $\begin{array}{l}\text { Long-term } \\
\text { sources of funds } \\
{[\mathbf{4} \text { to 6] }}\end{array}$ & $\mathbf{4 7 8 , 6 6 9 , 4 6 5}$ & $\mathbf{5 7 5 , 7 6 7 , 9 4 2}$ & $\mathbf{6 0 9 , 5 4 1 , 2 7 6}$ & $\mathbf{6 4 4 , 9 0 7 , 9 7 0}$ & $\mathbf{6 7 4 , 2 9 4 , 0 0 0}$ \\
\hline $\mathbf{9}$ & $\begin{array}{l}\text { Long Term } \\
\text { Financial Stability } \\
\text { Coefficient }[\mathbf{3} / \mathbf{8}]\end{array}$ & $\mathbf{1 . 1 5 4 4}$ & $\mathbf{1 . 1 0 5 5}$ & $\mathbf{1 . 1 0 3 8}$ & $\mathbf{1 . 0 8 5 7}$ & $\mathbf{1 . 0 7 1 6}$ \\
\hline
\end{tabular}

Source: Authors' calculations

Long-term Financial Stability Coefficient was used for performing of ACID test as it follows. (Table 4)

Table 4. Long-term ACID test - calculation

\begin{tabular}{|c|l|c|c|c|c|c|}
\hline$\#$ & \multicolumn{1}{|c|}{ Category / Year } & $\mathbf{2 0 1 5}$ & $\mathbf{2 0 1 6}$ & $\mathbf{2 0 1 7}$ & $\mathbf{2 0 1 8}$ & $\mathbf{2 0 1 9}$ \\
\hline 1 & Long-term tied assets & 1 & 1 & 1 & 1 & 1 \\
\hline 2 & Long Term Stability Coefficient & 1.1544 & 1.1055 & 1.1038 & 1.0857 & 1.0716 \\
\hline 3 & Long-term sources of funds $[1 / 2]$ & 0.8663 & 0.9045 & 0.9060 & 0.9211 & 0.9332 \\
\hline
\end{tabular}

Source: Authors' calculations

Based on the results of the ACID test, it is concluded that the long-term financial balance is shifted to long-term tied assets.

2 Thousands (K) of Serbian dinars (RSD)

http://ea.bg.ac.rs 
Figure 1. Long-term ACID test results - visual representation

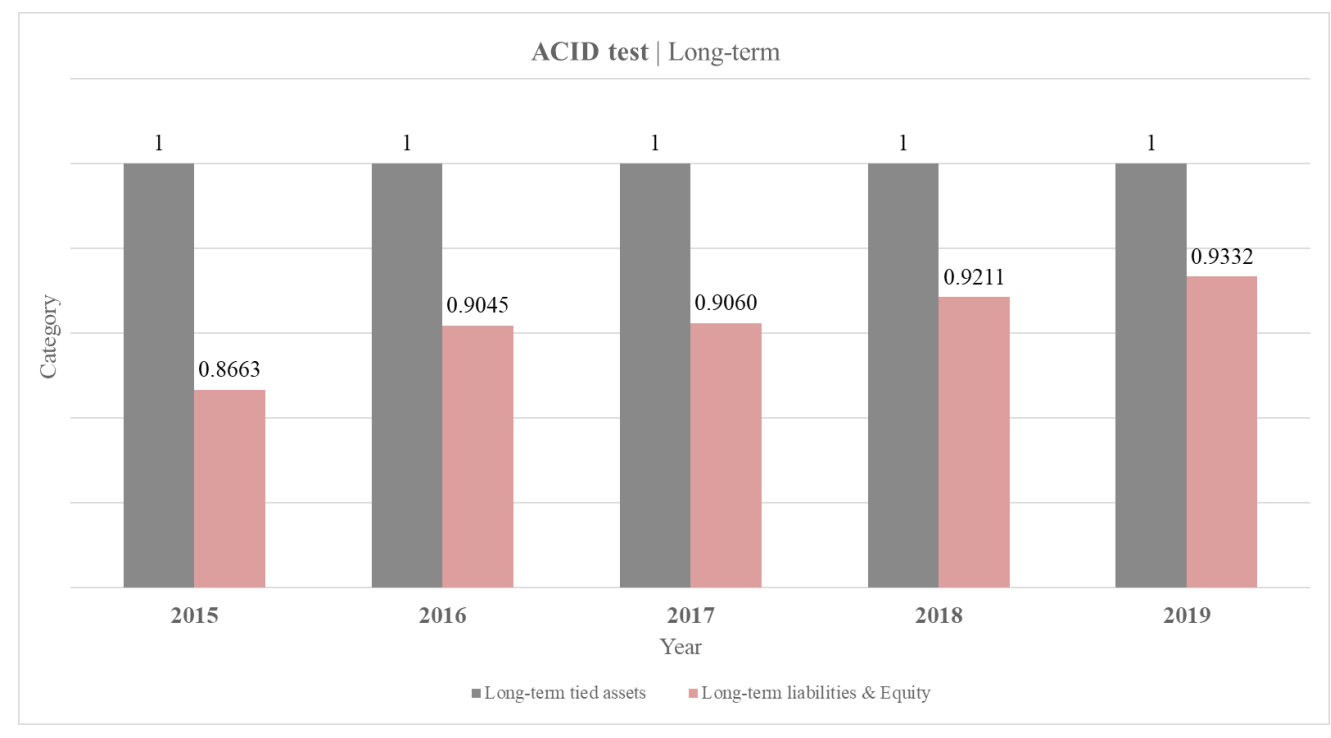

Source: Author

The test results indicate following:

- Every 100 dinars of long-term assets were covered with 86.63 dinars of longterm sources of funds in year 2015. The difference of 13.37\% [73,883,795 KRSD] was covered from short-term sources of funds.

- Every 100 dinars of long-term assets were covered with 90.45 dinars of longterm sources of funds in year 2016. The difference of 9.55\% [60,768,725 KRSD] was covered from short-term sources of funds.

- Every 100 dinars of long-term assets were covered with 90.60 dinars of longterm sources of funds in year 2017. The difference of $9.40 \%[63,269,226$ KRSD] was covered from short-term sources of funds.

- Every 100 dinars of long-term assets were covered with 92.11 dinars of longterm sources of funds in year 2018. The difference of 7.89\% [55,279,525 KRSD] was covered from short-term sources of funds.

- Every 100 dinars of long-term assets were covered with 93.32 dinars of longterm sources of funds in year 2019. The difference of $6.68 \%$ [48,277,670 KRSD] was covered from short-term sources of funds.

The fact there is a part of long-term assets financed from short-term sources of funds have a negative impact on the company's liquidity, because short-term liabilities are due for payment before the release of long-term tied assets. In perfect conditions, where the release of short-term tied assets absolutely matches the maturity and value of shortterm liabilities (1:1 ratio), difference between Equity increased by long-term liabilities 
on the one hand and long-term tied assets on the other hand would be equal to cash and liquid reserve. The previously mentioned situation is very rare in practice.

Taking everything into account, it can be concluded that enterprises in Serbian Agriculture, fishing, and forestry sector managed to maintain a long-term financial stability, because less than $15 \%$ of long-term assets was financed form short-term sources of funds during whole observed timeline. In dynamics, it can be concluded that there is a trend of long-term financial stability improvement, where the percentage of financing long-term assets with short-term sources of funds decreases from about 13\% in year 2015 to about 7\% in year 2019. Main leader of fast long-term financial stability improvement was enormous growth of equity.

Short-term (current) assets recorded a growth trend until year 2016, and situation is the same with short-term (current) liabilities. (Table 5) After that period, they recorded a decline in dynamics. The main cause of the decline in the value of short-term assets in year 2017 is a significant decline in sales receivables $(-5.3 \%)$. The main cause of the decline on the side of short-term liabilities is the balance sheet position "Other current liabilities" with a decrease of $17.7 \%$ compared to year 2016. Although a downward trend was recorded on both sides, short-term assets recorded a more intense decline rate, which affected the decline in the Short-term Financial Stability Coefficient until year 2017. From 2017 until the end of the observed period, the coefficient had a growing tendency, because of growth in current assets.

Table 5. Short-term financial stability analysis [balance sheet positions in KRSD]

\begin{tabular}{|c|l|c|c|c|c|c|}
\hline$\#$ & Category/ Year & $\mathbf{2 0 1 5}$ & $\mathbf{2 0 1 6}$ & $\mathbf{2 0 1 7}$ & $\mathbf{2 0 1 8}$ & $\mathbf{2 0 1 9}$ \\
\hline 1 & Cash \& Cash equivalents & $13,117,100$ & $15,224,538$ & $16,781,781$ & $17,745,429$ & $20,235,823$ \\
\hline 2 & $\begin{array}{l}\text { Sales, Specific business \& Other } \\
\text { receivables }\end{array}$ & $90,666,550$ & $98,477,667$ & $94,247,146$ & $96,264,977$ & $99,438,808$ \\
\hline 3 & Short-term financial investments & $21,218,491$ & $20,502,126$ & $20,198,745$ & $22,344,498$ & $21,988,308$ \\
\hline 4 & VAT & $2,998,314$ & $3,305,528$ & $4,133,230$ & $4,219,895$ & $3,955,125$ \\
\hline 5 & $\begin{array}{l}\text { Financial assets at fair value through } \\
\text { P\&L account }\end{array}$ & 372,624 & 152,776 & 103,903 & 100,498 & 115,938 \\
\hline 6 & Accrued expenses & $5,733,361$ & $6,627,521$ & $6,170,686$ & $5,567,827$ & $5,767,186$ \\
\hline 7 & $\begin{array}{l}\text { Liquid \& short-term tied assets } \\
{[\mathbf{1} \text { to 6] }}\end{array}$ & $\mathbf{1 3 4 , 1 0 6 , 4 4 0}$ & $\mathbf{1 4 4 , 2 9 0 , 1 5 6}$ & $\mathbf{1 4 1 , 6 3 5 , 4 9 1}$ & $\mathbf{1 4 6 , 2 4 3 , 1 2 4}$ & $\mathbf{1 5 1 , 5 0 1 , 1 8 8}$ \\
\hline$\#$ & \multicolumn{1}{|c|}{ Category/ Year } & $\mathbf{2 0 1 5}$ & $\mathbf{2 0 1 6}$ & $\mathbf{2 0 1 7}$ & $\mathbf{2 0 1 8}$ & $\mathbf{2 0 1 9}$ \\
\hline 8 & Current financial liabilities & $78,513,745$ & $84,053,299$ & $84,344,801$ & $80,221,476$ & $90,024,780$ \\
\hline 9 & Operating liabilities & $122,390,050$ & $118,261,818$ & $120,727,023$ & $124,736,209$ & $118,198,325$ \\
\hline 10 & Other current liabilities & $30,247,296$ & $30,538,830$ & $25,123,777$ & $23,996,903$ & $15,421,802$ \\
\hline 11 & $\begin{array}{l}\text { Liabilities for VAT, other taxes, } \\
\text { contributions, } \\
\text { other duties and deferred expenses }\end{array}$ & $10,365,830$ & $11,807,105$ & $11,629,143$ & $13,328,219$ & $12,559,668$ \\
\hline
\end{tabular}




\begin{tabular}{|c|l|c|c|c|c|c|}
\hline$\#$ & Category/ Year & $\mathbf{2 0 1 5}$ & $\mathbf{2 0 1 6}$ & $\mathbf{2 0 1 7}$ & $\mathbf{2 0 1 8}$ & $\mathbf{2 0 1 9}$ \\
\hline 12 & Prepayments, deposits and guarantees & $10,442,121$ & $7,670,351$ & $8,277,929$ & $8,372,146$ & $10,175,511$ \\
\hline 13 & $\begin{array}{l}\text { Short-term sources of funds } \\
{[8 \text { to 12] }}\end{array}$ & $\mathbf{2 5 1 , 9 5 9 , 0 4 2}$ & $\mathbf{2 5 2 , 3 3 1 , 4 0 3}$ & $\mathbf{2 5 0 , 1 0 2 , 6 7 3}$ & $\mathbf{2 5 0 , 6 5 4 , 9 5 3}$ & $\mathbf{2 4 6 , 3 8 0 , 0 8 6}$ \\
\hline 12 & $\begin{array}{l}\text { Short Term Financial Stability } \\
\text { Coefficient [7/13] }\end{array}$ & $\mathbf{0 . 5 3 2 3}$ & $\mathbf{0 . 5 7 1 8}$ & $\mathbf{0 . 5 6 6 3}$ & $\mathbf{0 . 5 8 3 4}$ & $\mathbf{0 . 6 1 4 9}$ \\
\hline
\end{tabular}

Source: Authors' calculations

The biggest impact on short-term assets growth in year 2018 and 2019 had the increase of Cash and Cash equivalents (up to 14\%) and increase of Sales receivables (up to 4.5\%). Short-term stability coefficient was used for ACID test calculation as it follows. (Table 6.)

Table 6. Short-term ACID test - calculation

\begin{tabular}{|c|l|c|c|c|c|c|}
\hline$\#$ & \multicolumn{1}{|c|}{ Category / Year } & $\mathbf{2 0 1 5}$ & $\mathbf{2 0 1 6}$ & $\mathbf{2 0 1 7}$ & $\mathbf{2 0 1 8}$ & $\mathbf{2 0 1 9}$ \\
\hline 1 & Short-term tied assets & 1 & 1 & 1 & 1 & 1 \\
\hline 2 & Short-term Stability Coefficient & 0.5323 & 0.5718 & 0.5663 & 0.5834 & 0.6149 \\
\hline 3 & Short-term sources of funds $[1 / 2]$ & 1.8788 & 1.7488 & 1.7658 & 1.7140 & 1.6263 \\
\hline
\end{tabular}

Source: Authors' calculations

Based on the results of the ACID test, it is concluded that the short-term financial balance was shifted to short-term liabilities in whole observed period.

Figure 2. Short-term ACID test results - visual representation

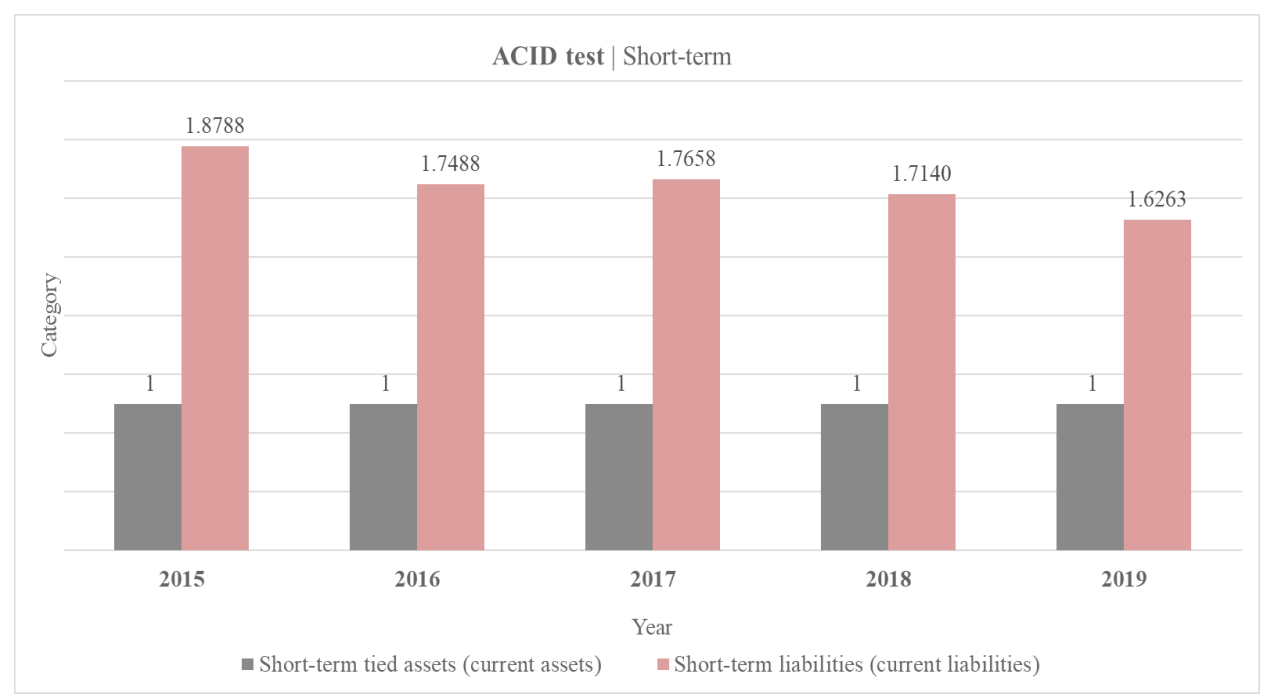

Source: Author 
The test results indicate following:

- Every 100 dinars of short-term assets were covered with 187.88 dinars of shortterm liabilities in year 2015. Maturity of short-term liabilities in this case should be longer than the maturity of short-term assets in average by $88 \%$ in order to maintain liquidity.

- Every 100 dinars of short-term assets were covered with 174.88 dinars of shortterm liabilities in year 2016. Maturity of short-term liabilities in this case should be longer than the maturity of short-term assets in average by $75 \%$ in order to maintain liquidity.

- Every 100 dinars of short-term assets were covered with 176.58 dinars of shortterm liabilities in year 2017. Maturity of short-term liabilities in this case should be longer than the maturity of short-term assets in average by $77 \%$ in order to maintain liquidity.

- Every 100 dinars of short-term assets were covered with 171.40 dinars of shortterm liabilities in year 2018. Maturity of short-term liabilities in this case should be longer than the maturity of short-term assets in average by $71 \%$ in order to maintain liquidity.

- Every 100 dinars of short-term assets were covered with 162.63 dinars of shortterm liabilities in year 2019. Maturity of short-term liabilities in this case should be longer than the maturity of short-term assets in average by $63 \%$ in order to maintain liquidity.

Short-term financial stability exists when ratio of short-term assets and short-term liabilities is $1: 1$. Observing the entire analyzed period, it is concluded that the enterprises did not manage to provide short-term financial stability, i.e. liquidity, because the balance was shifted towards short-term liabilities in every year. If the transition from year 2016 to year 2017 is omitted, it can be said that the enterprises are taking small steps to improve the situation related to short-term financial stability.

The next step of the analysis was to examine indebtedness. The indebtedness ratio is one of the most frequently used indicators of financial leverage. The rule applies to this ratio: the lower the value of the debt ratio, the greater the security of long-term creditors and the solvency of a company (Malinić et al., 2013).

Table 7. Indebtedness analysis [balance sheet positions in KRSD]

\begin{tabular}{|c|l|c|c|c|c|c|}
\hline$\#$ & $\begin{array}{c}\text { Category/ } \\
\text { Year }\end{array}$ & $\mathbf{2 0 1 5}$ & $\mathbf{2 0 1 6}$ & $\mathbf{2 0 1 7}$ & $\mathbf{2 0 1 8}$ & $\mathbf{2 0 1 9}$ \\
\hline 1 & Total liabilities & $339,331,402$ & $348,168,778$ & $352,466,612$ & $372,552,827$ & $376,691,009$ \\
\hline 2 & Equity & $391,297,105$ & $479,930,567$ & $507,177,337$ & $523,010,096$ & $543,983,077$ \\
\hline 3 & $\begin{array}{l}\text { Indebtedness } \\
\text { Coefficient } \\
{[1 / 2]}\end{array}$ & 0.87 & 0.73 & 0.69 & 0.71 & 0.69 \\
\hline
\end{tabular}

Source: Authors' calculations

http://ea.bg.ac.rs 
When it comes to indebtedness analysis (Table 7), the most unfavorable ratio of liabilities to equity was recorded in 2015. In the period from 2015 to 2017, a decrease in the debt ratio was recorded, which is a consequence of the faster equity growth compared to total liabilities. The sharp rise in total liabilities led to a minor increase of the ratio in 2018 and thus disrupted the downward trend in indebtedness. If the minor growth of indebtedness in 2018 is abstracted, it can be said that the enterprises are reducing their indebtedness at low rates during observed period.

Table 8. Interest coverage ratio [Income statement positions in KRSD]

\begin{tabular}{|c|l|c|c|c|c|c|}
\hline$\#$ & \multicolumn{1}{|c|}{ Category / Year } & $\mathbf{2 0 1 5}$ & $\mathbf{2 0 1 6}$ & $\mathbf{2 0 1 7}$ & $\mathbf{2 0 1 8}$ & $\mathbf{2 0 1 9}$ \\
\hline 1 & Operating profit & $9,159,312$ & $20,709,974$ & $11,813,064$ & $9,228,603$ & $10,107,337$ \\
\hline 2 & Interest expenses & $5,100,018$ & $4,847,169$ & $4,192,313$ & $3,782,181$ & $2,817,424$ \\
\hline 3 & $\begin{array}{l}\text { Interest cost coverage } \\
{[1 / 2]}\end{array}$ & 1.80 & 4.27 & 2.82 & 2.44 & 3.59 \\
\hline
\end{tabular}

Source: Authors' calculations

Value of interest coverage ratio should be 2 or higher. Enterprises in Serbian Agriculture, fishing, and forestry sector managed to maintain this ratio above reference value from 2016 to 2019 (Table 8). Lowest interest coverage was recorded in year 2015 (1.80), and highest interest coverage was recorded in year 2016 (4.27). During observed period, interest expenses reduction trend was recorded. Variations in ratio were caused by unstable amounts of operating profit from year to year. Enormous growth of interest coverage in 2016 is a consequence of extreme operating profit growth in transition from 2015 to 2016. Operating profit growth in year 2016 was driven by increase of income from goods sold and services provided. Also, reduction of raw material costs, salaries, but also fuel and energy costs contributed to the outcome. It cannot be said that the enterprises managed to improve this ratio indicator from year to year during the observed period. After the growth from year 2015 to 2016, the ratio recorded a decline until 2019.

Table 9. Return on Assets [Balance sheet and income statement positions in KRSD]

\begin{tabular}{|c|l|c|c|c|c|c|}
\hline$\#$ & Category / Year & $\mathbf{2 0 1 5}$ & $\mathbf{2 0 1 6}$ & $\mathbf{2 0 1 7}$ & $\mathbf{2 0 1 8}$ & $\mathbf{2 0 1 9}$ \\
\hline 1 & Operating profit & $9,159,312$ & $20,709,974$ & $11,813,064$ & $9,228,603$ & $10,107,337$ \\
\hline 2 & Total Assets & $686,659,700$ & $780,826,823$ & $814,445,993$ & $846,430,619$ & $874,072,858$ \\
\hline 3 & ROA $[1 / 2]$ & $1.33 \%$ & $2.65 \%$ & $1.45 \%$ & $1.09 \%$ & $1.16 \%$ \\
\hline
\end{tabular}

Source: Authors' calculations

The ROA indicator recorded a dynamic movement during the observed period. (Table 9) Significant growth from 2015 to 2016 is a consequence of far higher growth in operating profit compared to total assets. In 2016, the highest rate of this indicator was achieved. Until 2019, there was a decline in ROA because of the decline in operating profit, and enormous the growth of total assets. The largest contribution to the growth of total assets from 2015 to 2016 had Immovables, plants \& equipment, with a growth of 7,133,045 KRSD, Sales receivables (+ 6.838.421 KRSD), Inventories (+2,902,747 KRSD), as well as Cash and cash equivalents (+2.243.886 KRSD). When it comes to 
transition from 2016 to 2017, a huge decline of 4,403,077 KRSD in Sales receivables was recorded, but that decline was covered by growth of Immovables, plants \& equipment (+26,269,635 KRSD), Inventories (+7,731,219 KRSD) and Cash \& cash equivalents $(+1,557,243 \mathrm{KRSD})$. Until the end of observed period, total assets growth was driven by growth of Immovables, plants \& equipment, but also Sales receivables and Inventories.

Objectively, it cannot be said that the enterprises have a growing trend of ROA. Theorists agree with the statement that a good level of profitability is present when the ROA indicator is higher than 10\% (Dakić \& Mijić, 2020). Having in mind the above, the condition that theory finds as a reference value of profitability was not met.

Table 10. Return on Equity [Balance sheet and income statement positions in KRSD]

\begin{tabular}{|c|l|c|c|c|c|c|}
\hline$\#$ & Category/Year & $\mathbf{2 0 1 5}$ & $\mathbf{2 0 1 6}$ & $\mathbf{2 0 1 7}$ & $\mathbf{2 0 1 8}$ & $\mathbf{2 0 1 9}$ \\
\hline 1 & Net profit & $1,939,046$ & $9,257,299$ & $10,008,610$ & $-1,750,212$ & $6,184,712$ \\
\hline 2 & Equity & $391,297,105$ & $479,930,567$ & $507,177,337$ & $523,010,096$ & $543,983,077$ \\
\hline 3 & ROE $[1 / 2]$ & $0.50 \%$ & $1.93 \%$ & $1.97 \%$ & N/A & $1.14 \%$ \\
\hline
\end{tabular}

Source: Authors' calculations

The ROE indicator (Table 10) recorded a growth trend until year 2017, because of a higher net profit growth rate compared to equity growth. In 2018, the enterprises were operating at a loss and thus did not achieve a return on equity. After the loss, they recovered and achieved a return on equity of $1.14 \%$. In whole observed period, the enterprises did not manage to reach ROE higher than $2 \%$ which is far below referent values of $10-15 \%$. Considering the fact that in 2018 the enterprises operated with a loss, it can't be said that there is improving ROE trend during observed time. It is important to point out that in year 2019 the enterprises slowly started to recover with a net profit value of KRSD 6,184,712, which is a consequence of operating income growth and a significant reduction in operating expenses. The financial result was not driven by other, extraordinary, and accidental incomes.

\section{Discussions}

There is a strong correlation between long-term and short-term financial stability. The existence of stability on long-term side entails stability on the short-term side and vice versa. Enterprises in Serbian Agriculture, fishing and forestry sector can improve their financial stability by providing faster release of short-term tied assets compared to maturity of short-term liabilities. The possibility of implementing this recommendation generally depends on the position of products/services on the market, as well as the liquidity of customers. In addition, for the implementation of this recommendation, the possibility of suppliers to extend payment deadlines is of great importance.

Although there was a decline in indebtedness in the observed period, it is necessary to make additional effort in reducing the debt burden of equity, so that total debts do not exceed $50 \%$ of the equity value. To improve the position on interest coverage, it is 
recommended to ensure greater financial independence. More precisely, it is necessary to ensure the growth of operating profit with less bank loans in following years. Ultimately, it is possible to achieve operating profit increase even with growth of bank loans, and thus interest expenses growth from year to year. In that case, the enterprises should act with a clear goal and plan to ensure the growth of operating profit at a higher rate in comparison to growth rate of interest expenses.

The prerequisite to achieve a higher ROA is ensuring a higher level of assets usage and making sure that assets are used with much greater efficiency. That is the only way to make assets contribute more to the growth of operating profit. Improvement of ROE is possible by profit margin increase. That can be done in various ways, such as adjustments (rising) of product prices, further reducing of employee related costs and COGS, as well as reducing other operating expenses.

\section{Conclusions}

Although there is financing of long-term assets with short-term sources of funds present in the observed period, it can be said that enterprises in Serbian Agriculture, fishing, and forestry sector do not have disturbed long-term financial stability, given that in the whole period less than $15 \%$ of short-term sources were used to finance long-term assets. Therefore, hypothesis H1 is accepted as true - Enterprises in Serbian Agriculture, fishing and forestry sector manage to maintain acceptable level of longterm financial stability during observed period. Given the fact that in overall observed period short-term liabilities maturity needs to be extended in average by $63 \%$ or more compared to the maturity of short-term assets, it can be said that short-term financial stability is disturbed. Therefore, hypothesis H2 is accepted - Enterprises in Serbian Agriculture, fishing and forestry sector do not manage to maintain acceptable level of short-term financial stability. Considering that no ratio (neither interest coverage, nor indebtedness) achieved pure growth trend from year to year in the entire observed period - hypothesis $H 3$ is rejected. Although above mentioned ratios had a significant increase in several years, it was not perfect in terms of dynamics - there were many larger or smaller ups and downs in the values of indicators, especially when it comes to interest coverage indicator. The same applies to ROA and ROE, but these two indicators did not achieve a value even close to the reference value in any of the years covered by the analysis. Hypothesis $H 4$ is rejected.

\section{Conflict of interests}

The author declares no conflict of interest. 


\section{References}

1. Bogdanov, N. \& Vasiljević, Z. (2011). Role of Agricultural and Multifunctional Rural Development in Serbia. APSTRACT: Applied Studies in Agribusiness and Commerce. Agroinform Publishing House, Budapest, 46-55. (Available at: https:// ojs.lib.unideb.hu/apstract/article/view/7691/7045 date of access 15.02.2021.)

2. Bogdanov, N., \& Rodić, V. (2014). Agriculture and Agricultural Policy in Serbia. Chapter in Agricultural Policy and European Integration in Southeastern Europe. Food and Agriculture Organizaiton of the United Nations, Budapest, 153-171. (Available at: http://sebina.iamb.it/sebina/repository/catalogazione/immagini/ pdf/Agricultural\%20policy\%20and\%20european\%20integration.pdf\#page $=161$, date of access 15.02.2021.)

3. Business Registers Agency, Financial Statements Annual Bulletins, Belgrade, Available at: https://www.apr.gov.rs/registri/finansijskiizvestaji/publikacijel godisnji--bilten-finansijskih-izvestaja.2127.html date of access: 10.02.2021.)

4. Dakić, S. \& Mijić, K. (2020). Regression analysis of the impact of internal factors on return on assets: a case of meat processing enterprises in Serbia. Strategic Management, 25(1), 29-34

5. Dauderis, H. \& Annand, D. (2014). Introduction to Financial Accounting. Valley Educational Services, Canada.

6. Fridson, M. \& Alvarez, F. (2002). Financial Statements Analysis. John Wiley \& Sons Inc., New York

7. Gibson, H., C. (2000). Financial Reporting \& Analysis. Cengage Learning, Boston

8. Kabajeh, M., A., M., Nu'aimat, A.,M.,S. \& Dahmash, N., F. (2012). The relationship between the ROA, ROE and ROI Ratios with Jordanian Insurance Public Companies Market Share Prices. International Journal of Humanities and Social Science 2(11), 115-120.

9. Kulkarni, M. \& Mahajan, S. (2008). Management Accounting. Nirali Prakashan, Mumbai.

10. Kuzman, B., Djurić, K., Mitrović, Lj. \& Prodanović, R. (2017). Agricultural Budget and Agriculture Development in Republic of Serbia. Economics of Agriculture, 64(2), 515-531.

11. Malinić, D., Milićević, V. \& Stevanović, N.. (2013). Management Accounting. Publishing Center of the Faculty of Economics, Belgrade. [In Serbian: Малинић, Д., Милићевић, В., Стевановић, Н. Управљачко рачуноводство]

12. Miljković, A. (2008). Financial Analysis. Academic of Economics, Novi Sad [In Serbian: Миљковић, А. (2008). Финансијска анализа].

13. Mitrović, S., Mitrović, A. \& Cogoljević, M. (2017). Contribution of Agriculture to the Development of Serbia. Economics of Agriculture, 64(2), 805-819. 
14. Nuryani, Y. \& Sunarsi, D. (2020). The Effect of Current Ratio and Debt to Equity ratio on Dividing Growth. JASa. 4(2), 304-312

15. Palepu, K., G., Bernard, V., L. \& Healy, P., M. (2000). Business Analysis \& Valuation Using Financial Statements. South-Western, USA

16. Paramasivan, C. \& Subramanian, T. (2009). Financial Management. New Age International Ltd. Publishers, New Delhi.

17. Robinson, R., T., Greuning, V., H. \& Broihahn, A., M. (2009). International Financial Statements Analysis. John Wiley \& Sons, Inc., New Jersey.

18. Rodić, J., Andrić, M., Vukelić, G., \& Vuković, B. (2017). Financial Statements Analysis. Faculty of Economics, Subotica. [In Serbian: Родић, J., Андрић, М., Вукелић, Г., Вуковић, Б. (2017). Анализа финансијских извештаја].

19. Subramanyam, R., K. \& Wild, J., J. (2009). Financial Statement Analysis. McGraw-Hill, New York.

20. Vunjak, N. (2014). Financial Management. Proleter Ltd., Bečej [In Serbian: Вуњак, Н. (2008). Финансијски менаџмент]. 